\title{
RESEARCH
}

Open Access

\section{Development and validation of broad- spectrum magnetic particle labelling processes for cell therapy manufacturing}

Richard Harrison', Hilda Anaid Lugo Leija', Stephanie Strohbuecker', James Crutchley', Sarah Marsh', Chris Denning ${ }^{1}$, Alicia El Haj ${ }^{2}$ and Virginie Sottile ${ }^{1^{*}}$ (I)

\begin{abstract}
Background: Stem cells are increasingly seen as a solution for many health challenges for an ageing population. However, their potential benefits in the clinic are currently curtailed by technical challenges such as high cell dose requirements and point of care delivery, which pose sourcing and logistics challenges. Cell manufacturing solutions are currently in development to address the supply issue, and ancillary technologies such as nanoparticle-based labelling are being developed to improve stem cell delivery and enable post-treatment follow-up.

Methods: The application of magnetic particle (MP) labelling to potentially scalable cell manufacturing processes was investigated in a range of therapeutically relevant cells, including mesenchymal stromal cells (MSC), cardiomyocytes (CMC) and neural progenitor cells (ReN). The efficiency and the biological effect of particle labelling were analysed using fluorescent imaging and cellular assays.

Results: Flow cytometry and fluorescent microscopy confirmed efficient labelling of monolayer cultures. Viability was shown to be retained post labelling for all three cell types. MSC and CMC demonstrated higher tolerance to MP doses up to 100x the standard concentration. This approach was also successful for MP labelling of suspension cultures, demonstrating efficient MP uptake within $3 \mathrm{~h}$, while cell viability was unaffected by this suspension labelling process. Furthermore, a procedure to enable the storing of MP-labelled cell populations to facilitate cold chain transport to the site of clinical use was investigated. When MP-labelled cells were stored in hypothermic conditions using HypoThermosol solution for 24 h, cell viability and differentiation potential were retained post storage for ReN, MSC and beating CMC.

Conclusions: Our results show that a generic MP labelling strategy was successfully developed for a range of clinically relevant cell populations, in both monolayer and suspension cultures. MP-labelled cell populations were able to undergo transient low-temperature storage whilst maintaining functional capacity in vitro. These results suggest that this MP labelling approach can be integrated into cell manufacturing and cold chain transport processes required for future cell therapy approaches.
\end{abstract}

Keywords: Magnetic particles, Cell functionalisation, Cell therapy, Stem cells, Cell labelling

\footnotetext{
* Correspondence: virginie.sottile@nottingham.ac.uk

${ }^{1}$ Wolfson Centre for Stem Cells, Tissue Engineering and Modelling (STEM),

School of Medicine, The University of Nottingham, Nottingham NG7 2RD, UK

Full list of author information is available at the end of the article
}

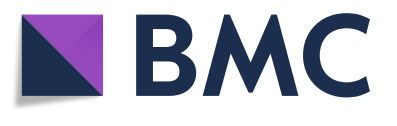

(c) The Author(s). 2018 Open Access This article is distributed under the terms of the Creative Commons Attribution 4.0 International License (http://creativecommons.org/licenses/by/4.0/), which permits unrestricted use, distribution, and reproduction in any medium, provided you give appropriate credit to the original author(s) and the source, provide a link to the Creative Commons license, and indicate if changes were made. The Creative Commons Public Domain Dedication waiver (http://creativecommons.org/publicdomain/zero/1.0/) applies to the data made available in this article, unless otherwise stated. 


\section{Background}

Emerging cell-based therapies are demonstrating promising solutions to a wide range of debilitating health concerns facing global healthcare systems [1]. A number of stem cell sources are currently being researched for a range of potential applications yet challenges still exist, particularly with reproducible manufacturing, distribution [2, 3] and minimising costs of goods [4]. In addition to this, the mechanism of action underpinning many of these therapies remains largely unknown and subsequent cell dose requirements are high [5]. Better cell targeting strategies may help overcome some of these challenges, and magnetic particle (MP) labelling represents an attractive means to facilitate this targeting [6]. Magnetic targeting allows non-invasive imaging of administered cells post implantation [7], which can help measure efficacy and thus provide follow-up characterisation and safety data in the early stages of development [8]. Together, this spatial control over grafted cells and increased understanding with follow-up imaging have the potential to significantly improve the efficacy, specificity and impact of cell therapies for patient benefit [9].

MPs possess a wide variety of interesting and sometimes contrasting properties which make them useful for a multitude of biological and biomedical applications. With strong permanent magnets and superconducting electromagnets, a range of field strengths, gradients and durations are available for potential applications in multiple medical disciplines. The use of small magnetic particles for in-vitro diagnostics has been commonplace for almost 40 years [10-12]. The biomedical applications of magnetic particles have evolved over these years into a multidisciplinary field, which harnesses magnetic materials for a variety of applications. These multi-functional tools are often described as theranostics and describe the delivery of an active therapeutic payload to a cell whilst providing diagnostic information on its location [13].

The avenues that magnetic targeted therapeutics can take are diverse, including active material coatings [14], drug payloads [15] or targeted hyperthermia [16] to ablate carcinoma lesions at the cellular level. A multitude of research groups are working towards creating labelling solutions for stem cells, cell therapies and regenerative medicine products. The potential benefits of these products could include both magnetic tracking [17] and targeting [18] strategies, as well as sensory [19] and activation [20] particles.

MP cell tracking approaches are afforded through the use of magnetic resonance imaging (MRI). MP-based imaging stems from the first use of MRI contrast agents, which emerged around 1981-1982 [21] and allow identification of specific labelled areas within biological organisms. Recent advances in the MRI technique have enabled real-time qualitative analysis of in-vivo tissues providing real-time observations of disease progression or therapeutic efficacy $[19,22]$. MRI is also of benefit to emerging targeting approaches using electromagnetic fields to guide magnetic particles. This technique utilises the magnetic scanner to guide magnetic objects and has been demonstrated to successfully deliver cell suspensions to the myocardium in animal models [23]. Permanent magnet-based approaches for magnetic cell temporal control are more common and have been demonstrated extensively in the wider literature. Magnetic induced migration of labelled cells towards specific areas in vivo has been shown for multiple tissue types, including the vasculature [24-30], retina [31, 32], CNS [33] and liver [34]. Finally, magnetically labelled cells have demonstrated utility in construction and handling of cell sheets for retinal applications [32] as well as engraftment into scaffold-like structures such as stents [35, 36]. This suggests some tissue engineering approaches may also benefit from labelled cell sources.

Despite the capability promised by developers of MPs to enhance the end regenerative medicine products [37], few of these products have been validated for clinical use [38]. Similarly, relatively little interest has been paid to how these MP theranostics could be incorporated into potentially scalable cell manufacturing platforms. Rather, existing published research focuses on labelling strategies in planar culture systems which would be unsuitable for wide-scale adoption [38]. Similarly, distribution of cell-based therapies has been under-studied and only recently is significant investment taking place in this space [2].

In order to produce the quantities of biological material for mainstream adoption of regenerative medicine and cell therapies, scale up production methodologies are needed. This should deliver any economies of scale and thus drive production costs down. We have previously described a safe and efficacious MP labelling strategy for human mesenchymal stromal cells (MSC) and demonstrated its utility as a multifunctional cell tracking and manipulation tool [38]. This paper describes labelling strategies using two MP size ranges (500 $\mathrm{nm}$ and $1000 \mathrm{~nm}$ ) to label three therapeutically relevant stem cell populations: human bone marrow-derived MSC, iPS-derived human cardiomyocytes (CMC) and ReNeuron neural stem cells (ReN). We further describe how this can be integrated into the pooling or holding stage of a simulated cell manufacturing process and how the resultant cell product could be shipped at low temperature $\left(4{ }^{\circ} \mathrm{C}\right)$ to a clinical environment in a ready-to-use state.

\section{Methods}

All reagents were purchased from ThermoFisher Scientific (UK) unless otherwise stated. 


\section{Human mesenchymal stromal cell culture}

A human bone marrow-derived mesenchymal stromal cell line [38] (also known as mesenchymal stem cells) was cultured and expanded under standard cell culturing conditions $\left(37^{\circ} \mathrm{C}, 5 \% \mathrm{CO}_{2}\right)$ in standard culture medium consisting of Dulbecco's modified Eagle's medium (DMEM) supplemented with 10\% (v/v) FBS, 1\% (v/v) non-essential amino acids, $1 \mathrm{mM}$ L-glutamine, $1 \mathrm{mM}$ pyruvate and $1 \%$ penicillin/streptomycin. Cells were passaged using trypsin/EDTA. Primary mesenchymal stromal cells (pMSC) were isolated from human bone marrow aspirate (Lonza, UK) [39].

\section{Human neural stem cell culture}

Immortalised ReNeuron VM cells (ReN) [40] were cultured on laminin-coated vessels in ReN NSC maintenance medium containing B27 neural cell supplement mix, bFGF (10 ng/ml) and EGF (20 ng/ml; Sigma Aldrich, UK). Cells were passaged every 3-4 days using trypsin $(0.25 \%)$ and soybean trypsin inhibitor (Sigma Aldrich) solutions. Briefly, cells were rinsed with phosphate buffered saline (PBS) and then incubated in trypsin $(0.25 \%)$ solution for 5-15 min until the cells detached. Twice the volume of soybean trypsin inhibitor (Sigma Aldrich) was added and the cells were centrifuged at $500 \times g$ for $5 \mathrm{~min}$. The cell pellet was re-suspended in fresh medium and plated in freshly laminin-coated flasks at a density of $\sim 10,000$ cells $/ \mathrm{cm}^{2}$. All experiments presented in this study were carried out on cells between passages 5 and 8 .

\section{Human iPS-derived cardiomyocyte cell culture}

Cardiomyocytes (CMC) [41] were thawed, transferred to RPMI-B27 medium and centrifuged at $300 \times g$ for $3 \mathrm{~min}$. Cells were re-suspended in RPMI-B27 containing $10 \mu \mathrm{M}$ ROCK inhibitor (Tocris Biotechne) and plated, with a first medium change carried out after $48 \mathrm{~h}$ with RPMI-B27 only. Subsequent medium changes were carried out thereafter at intervals of 2-3 days without ROCK inhibitor.

\section{Human cancer cell lines}

HeLa (cervical cancer cell line) [42], HOS (human osteosarcoma cell line) [43], SHSY5Y (human neuroblastoma-derived cell line) [44] and Caco-2 (human epithelial colorectal adenocarcinoma cells) [45] were cultured and expanded in standard culture medium consisting of DMEM supplemented with $10 \%$ (v/ v) FBS, $1 \%(\mathrm{v} / \mathrm{v})$ non-essential amino acids, $1 \mathrm{mM}$ L-glutamine, $1 \mathrm{mM}$ pyruvate and $1 \%$ penicillin/streptomycin. Cells were passaged using trypsin/EDTA.

\section{Mouse embryonic stem cell culture}

Mouse embryonic stem cells (ESC) were cultured in DMEM supplemented with $1.7 \mathrm{mM}$ L-glutamine, $0.1 \mathrm{mM}$ $\beta$-mercaptoethanol, $5 \mathrm{ng} / \mathrm{ml}$ mouse leukaemia inhibitory factor (LIF), $10 \%(\mathrm{v} / \mathrm{v})$ FBS, $1 \%(\mathrm{v} / \mathrm{v})$ non-essential amino acids, $1 \mathrm{mM}$ pyruvate and $1 \%$ penicillin/streptomycin (stock 10,000 U/ml) without a feeder layer. Cells were dissociated by $0.05 \%$ trypsin/EDTA.

\section{Cell labelling with magnetic particles}

Cells were seeded at $40 \%$ confluency and grown to $80 \%$ confluency before labelling. Fluorescently tagged magnetic particles of $500 \mathrm{~nm}$ and $1000 \mathrm{~nm}$ (ScreenMAG-Silanol, Chemicell, Germany) were used for cell labelling. Labelling of cell monolayers was performed as described previously [38, 46]. Briefly, adherent cell populations were incubated with MPs $(10 \mu \mathrm{g} \mathrm{Fe} / \mathrm{ml}$ standard dose or $25 \mu \mathrm{g} \mathrm{Fe} / \mathrm{ml}$ for fully confluent cultures) in medium for $24 \mathrm{~h}$. The next day, cells were thoroughly washed with PBS in order to remove excess particles attached to the cell surface or flask. For suspension cell labelling, MSC, $\mathrm{CMC}$ and $\mathrm{ReN}$ were evenly suspended in $7 \mathrm{ml}$ growth medium without serum and MPs were added at $70 \mu \mathrm{g}$ Fe of particles per $1 \times 10^{6}$ cells. Cells were agitated at 60 RPM for $3 \mathrm{~h}$ and labelled suspensions were then centrifuged to remove excess particles before plating out or direct flow cytometry after fixation with $4 \%$ ice-cold paraformaldehyde (PFA) (VWR, UK).

\section{Particle labelling assessment}

To measure particle uptake by flow cytometry, cells were harvested, centrifuged at $200 \times g$ for $5 \mathrm{~min}$ and re-suspended in PBS prior to analysis. Fixed samples from suspension labelling were analysed in PBS immediately following PFA fixation. Labelled and unlabelled populations were compared to evaluate the percentage uptake based on fluorescent intensity. Analysis was performed on a Beckman Coulter FC500 8HT Flow Cytometer (Beckman Coulter, USA) with WEASEL (WEHI, Australia), using unlabelled cells as controls to evaluate increased fluorescence.

Particle uptake was further evaluated visually using fluorescence and super-resolution microscopy. Adherent cells from monolayer cultures or plated out after suspension culture were fixed with 4\% PFA and stained using FITC-labelled Phalloidin (Life Technologies, USA) according to the manufacturer's instructions [38, 47], following permeabilisation with $0.1 \%$ Triton $\mathrm{X}-100$ for 5 min. Slides were incubated in a dark covered container at room temperature for $15 \mathrm{~min}$, and then washed twice with PBS and counterstained with Hoechst 33342 (Sigma Aldrich, UK). Cells were then imaged using the Operetta High Content Analysis System (Perkin Elmer, USA). For super-resolution microscopy, CMC were seeded in Matrigel-coated glass-bottom culture dishes (MatTek Corporation, USA) and left to attach and beat 
for 3 days. Cells were then labelled with $10 \mu \mathrm{g} \mathrm{Fe} / \mathrm{ml}$ for $24 \mathrm{~h}$, washed three times with PBS and fixed with PFA.

\section{MSC osteogenic differentiation}

MSC were seeded at $5 \times 10^{3}$ cells $/ \mathrm{cm}^{2}$ and the medium was then changed every 3 days for 14 days with either control medium or osteogenic induction medium containing DMEM supplemented with $100 \mathrm{nM}$ dexamethasone, $0.05 \mathrm{mM}$ L-ascorbic acid-2-phosphate and $10 \mathrm{mM}$ $\beta$-glycerophosphate. Mineralised nodules were identified using Von Kossa staining [48]. Cells were fixed at room temperature for $15 \mathrm{~min}$ in $4 \%$ PFA, washed three times with $\mathrm{dH}_{2} \mathrm{O}$ and incubated with $1 \%$ silver nitrate in $\mathrm{dH}_{2} \mathrm{O}$ (Sigma Aldrich) under a UV lamp for $15 \mathrm{~min}$. Samples were washed three times with $\mathrm{dH}_{2} \mathrm{O}$, incubated for 5 min with $2.5 \%$ sodium thiosulfate solution (Sigma Aldrich), washed again with $\mathrm{dH}_{2} \mathrm{O}$ and imaged using an eclipse TS100 inverted microscope (Nikon, Japan).

\section{ReN differentiation}

Cells were seeded at 10,000 cells/well onto laminincoated 96-well plates (BD Biosciences) and expanded for 2 days in growth medium before initiating differentiation using ReN culture medium without growth factors [40]. After 7 days of differentiation, cells were fixed in 4\% paraformaldehyde (PFA) for immunocytochemistry analysis.

\section{Cell viability assessment}

Viability was evaluated using the resazurin metabolic assay, using a working solution consisting of $10 \%(\mathrm{v} / \mathrm{v})$ Presto Blue stock solution prepared according to the manufacturer's instructions. After 45-min incubation, the fluorescent signal of $100 \mu \mathrm{l}$ samples was measured at $535 \mathrm{~nm}$ excitation and $615 \mathrm{~nm}$ emission in triplicate, using an Infinite 200 PRO plate reader and i-control software (Tecan, Switzerland). The positive control consisted of unlabelled cells which remained in monolayers for the duration of the labelling time period, and the negative control consisted of cells exposed to 70\% methanol in $\mathrm{H}_{2} \mathrm{O}$ fixative for 10 min followed by $3 \times$ PBS washing.

\section{HypoThermosol refrigerated storage of cells}

MSC, CMC and ReN at full confluency were removed from the incubator and the media exchanged with $4{ }^{\circ} \mathrm{C}$ HypoThermosol FRS preservation solution (BioLife Solutions, USA). Plates were then sealed with Parafilm (Bemis NA, USA) and stored at $4{ }^{\circ} \mathrm{C}$ for $24 \mathrm{~h}$. Cells were then removed from refrigerated storage, and the HypoThermosol solution was replaced with warmed media. A recovery period of $48 \mathrm{~h}$ was then allowed prior to assessment or fixation with 4\% PFA. Assessment of cells before and after HypoThermosol incubation was performed using bright-field microscopy. Images and videos were acquired using an eclipse TS100 inverted microscope (Nikon, Japan).

\section{Statistical analysis}

Statistical analysis was in the form of ANOVA performed using GraphPad PRISM (GraphPad Software, USA). Significance was shown as $* P \leq 0.05, * P \leq 0.01$, $* * * P \leq 0.001$ and $* * * * * 0.0001$.

\section{Results}

Efficient cell labelling applicable to multiple cell types

Therapeutically relevant cell types were cultured with fluorescently labelled MPs $(10 \mu \mathrm{g} / \mathrm{ml})$ in order to test the broad efficiency of the labelling strategy for regenerative medicine applications (Fig. 1). After $24 \mathrm{~h}$ of incubation, flow cytometry measurement showed labelling efficiencies ranging from above $23 \%$ (Caco-2 and mouse embryonic stem cells) to $>90 \%$ (HeLa, HOS, MSC and SHSY5Y) (Fig. 1a-f). Fluorescence imaging of three clinically relevant human cell types-cardiomyocytes derived from pluripotent embryonic stem cells (CMC), bone marrow-derived mesenchymal stromal cells (MSC) and neuroprogenitor cells (ReN)-incubated with fluorescent MPs using the same approach confirmed the intracellular labelling after $24 \mathrm{~h}$ (Fig. 1g-i).

In order to assess the tolerance of these different cell types to the labelling procedure, metabolic activity was assessed at $24 \mathrm{~h}$ post labelling (Fig. 2), using $500 \mathrm{~nm}$ and $1000 \mathrm{~nm}$ MPs. No significant difference in relative viability was observed in MSC, ReN or CMC upon incubation with $500 \mathrm{~nm}$ or $1000 \mathrm{~nm}$ MPs after $24 \mathrm{~h}$ (Fig. 2a-c). At the standard $10 \mu \mathrm{g} / \mu \mathrm{l}$ concentration, cell viability was above $80 \%$, indicating that magnetic labelling did not affect the cell cultures. Further viability, senescence and cell cycle profile assessments confirmed the maintenance of cellular integrity upon labelling (Additional file 1: Figure S1). Similarly, the unaffected morphology and viability of beating CMC were confirmed through observation of beating colonies (see methods in Additional file 2: Supplementary information, and videos of beating $\mathrm{CMC}$ colonies in Additional file 3: Figure S2 and Additional file 4: Figure S3).

\section{Cell labelling approach for suspension cultures}

In order to assess the possibility of integrating MP labelling strategies within existing cell manufacturing platforms, labelling of cells was performed in suspension cultures. These corresponded to the cell pooling stages, where cells may be held in suspension between unit operations of a manufacturing process $[49,50]$. This was evaluated for a range of cell types to show utility across a range of therapeutically relevant cells.

Suspensions of ReN, MSC and CMC were incubated with fluorescently tagged microparticles using two 

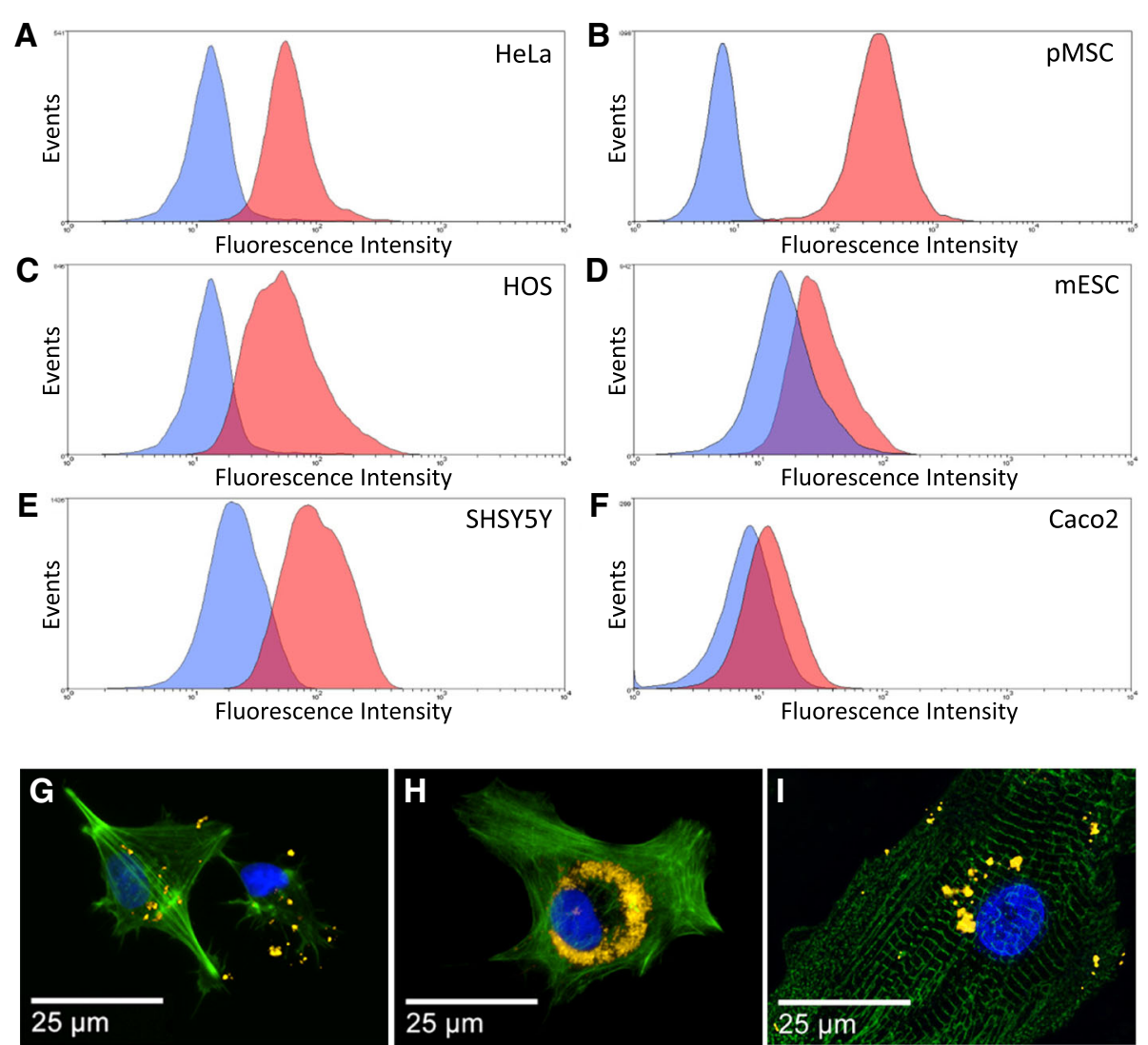

Fig. 1 Microparticle-based labelling of adherent cultures incubated for $24 \mathrm{~h}$ in medium containing $1000 \mathrm{~nm} \mathrm{MPs} \mathrm{(10} \mathrm{\mu g/ \mu l).} \mathrm{a-f} \mathrm{Flow}$ cytometry measurement of labelled (pink) and unlabelled (blue) cell populations analysed $24 \mathrm{~h}$ post incubation: a HeLa (cervical cancer stem cell line), b pMSC (primary mesenchymal stem cells), c HOS (human osteosarcoma stem cell line), d mESC (mouse embryonic stem cells), e SHSY5Y (human neuroblastoma derived stem cell line), f Caco-2 (human epithelial colorectal adenocarcinoma cells). Representative data shown, $n=3$. $\mathbf{g}$-i Fluorescence microscopy observation of neuroprogenitors (ReN, $\mathbf{g}$ ), mesenchymal stem cells (MSC, h), and iPS-derived cardiomyocytes (CMC, i) incubated overnight with MPs (gold), stained with Phalloidin (green) and Hoechst 33342 (blue)

different sizes (500 nm and $1000 \mathrm{~nm})(10 \mu \mathrm{g} / \mathrm{ml})$ (Fig. 3). Successful labelling was confirmed with fluorescent microscopy for MSC (Fig. 3a), CMC (Fig. 3e) and ReN (Fig. 3f). The highest labelling levels were detected in MSC, as compared to CMC and ReN, although for the latter two the MP labelling was suboptimal for the imaging filters used in the microscope due to the maximum emission spectra not overlapping with the filters present. The labelling efficiency of MSC in suspension cultures was further examined by flow cytometry (Fig. 3b), which showed over $98 \%$ labelling of both MP types. Membrane integrity assays demonstrated no significant alterations in MSC populations after suspension labelling (Fig. 3c). Metabolic activity assayed $24 \mathrm{~h}$ after cell labelling indicated that MSC, CMC and ReN retained their relative viability following this suspension labelling procedure (Fig. 3d, g, h).

\section{Cold chain transport of therapeutically relevant labelled cells}

The final component of the manufacturing value chain is transportation and distribution to the end user. This often overlooked step occurs outside the manufacturing facility and is a significant risk factor for introducing unknown changes to the final cell therapy product. The final stage transport of therapeutically relevant labelled cells was examined using HypoThermosol FRS as a transport medium in refrigerated environments. MSC, CMC and ReN were labelled with MP and stored in HypoThermosol preservation medium for $24 \mathrm{~h}$ at $4{ }^{\circ} \mathrm{C}$ to evaluate subsequent viability, functionality and label retention. Following a 24-h recovery period at $37{ }^{\circ} \mathrm{C}$, cells were examined for metabolic activity as a measure of their relative viability (Fig. 4). No statistically significant decrease was detected in relation to the hypothermic incubation step, suggesting cells returned to basic metabolic activity post storage. 


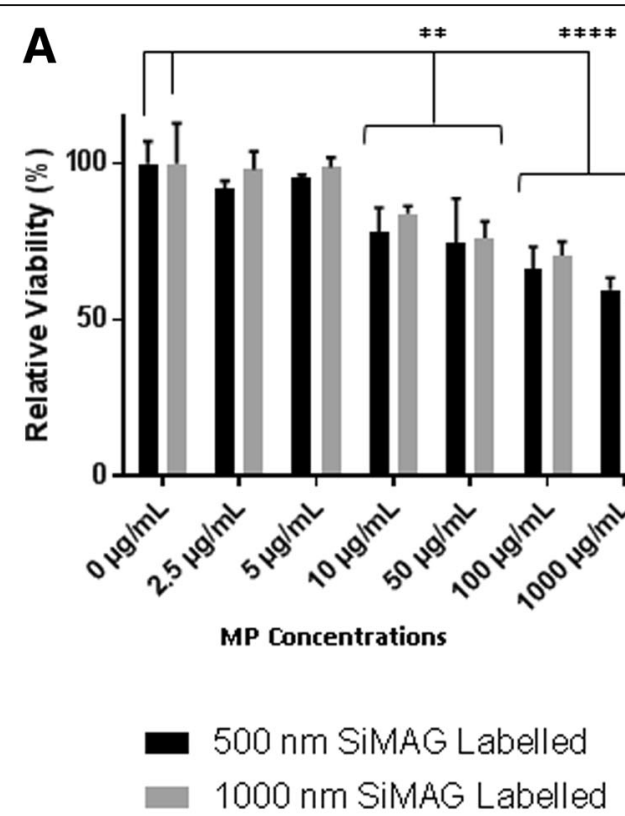

B
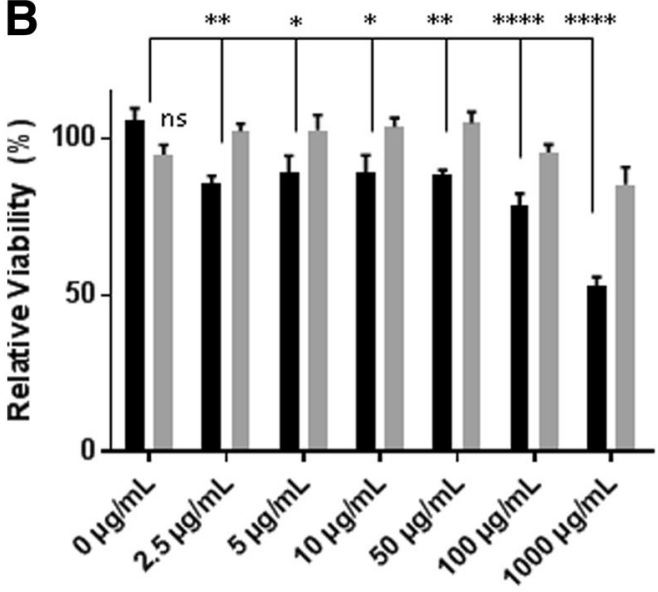

MP Concentrations

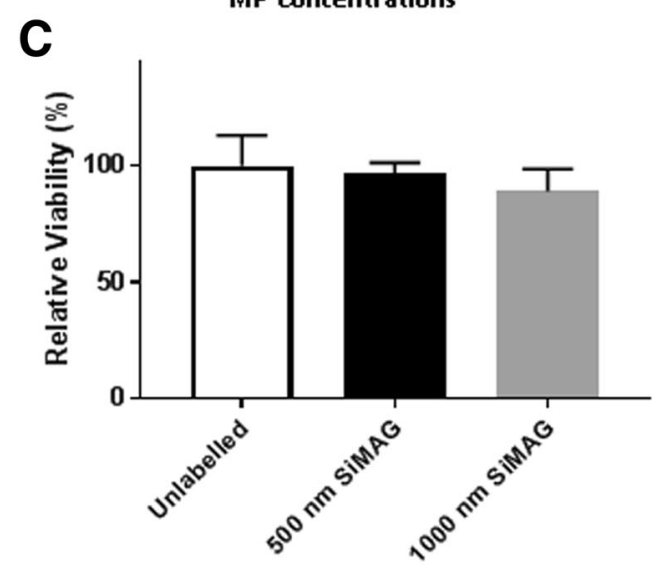

Treatment Groups
Fig. 2 Metabolic activity measurements of MSC (a), CMC (b) and ReN (c) cultures at $24 \mathrm{~h}$ post labelling using $500 \mathrm{~nm}$ and $1000 \mathrm{~nm}$ MPs at a range of concentrations $(\mathbf{a}, \mathbf{b})$ including the standard $10 \mu \mathrm{g} / \mathrm{ml}$ dose (c). Error bars presented as SEM, $n=8(\mathbf{a}, \mathbf{b})$ and $n=3$ (c). ${ }^{*} P \leq 0.05,{ }^{* *} P \leq 0.01,{ }^{* * *} P \leq 0.0001$. MP magnetic particle

It is crucial that cells remain not only viable but also functional. Previous work has examined tri-lineage differentiation of MSCs with and without iron MP labelling, demonstrating no impairment on the cells' ability to differentiate $[38,46]$. Thus, a simple indicator of functionality was examined for each cell type following the low-temperature storage (Fig. 5). MSC function was indicated using an osteogenic differentiation assay applied post 24-h storage. Von Kossa staining at day 14 highlighted mineralisation and the retention of their differentiation ability following labelling and storage of cells (Fig. 5a). Differentiation of the ReN carried out for 7 days post 24-h hypothermal storage indicated that both unlabelled and MP-labelled cells retained their ability to differentiate towards neuronal and glial lineages (Fig. 5b).

The morphology and functional ability of CMC to spontaneously beat was observed through bright-field imaging after $24 \mathrm{~h}$ (Additional file 5: Figure S4). This was further characterised through quantitation of alpha actinin immunodetection, which demonstrated expression in CMC following HypoThermosol incubation, albeit at a reduced level (Additional file 6: Figure S5).

\section{Discussion}

Micron-sized iron oxide particles have demonstrated excellent utility for tracking by MRI, and early research suggests they have additional utility as theranostic agents [7, 51, 52]. Future cell therapies will require the adoption of scalable manufacturing processes enabling large-scale, reproducible manufacture $[5,53]$ that can be integrated into the manufacturing value chain rather than added post production, such as cell labelling [54].

Here, an approach to label a range of cell types efficiently with MPs was investigated. Labelling for $24 \mathrm{~h}$ was shown to be effective, and noted to be more efficient for larger cell types such as HeLa cells or MSC when compared to relatively smaller cells such as mouse embryonic stem cells or Caco- 2 cells. When examining three therapeutically relevant human cell types, this was further confirmed as the smaller neuroprogenitor cells were observed to take up fewer particles than the larger CMC or MSC. Despite this, efficient MP labelling was demonstrated in monolayers for the MSC, CMC and 


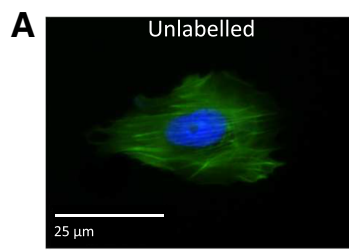

B
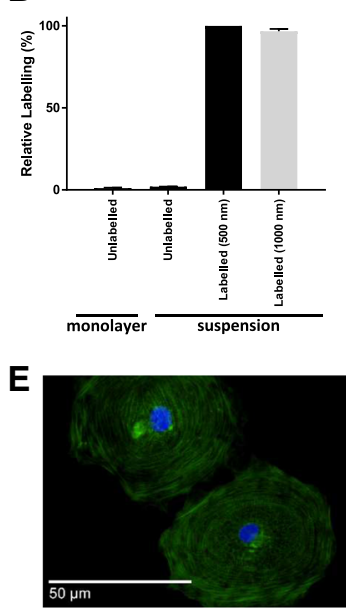

$\mathbf{F}$

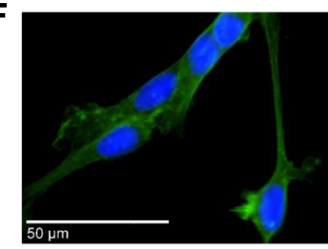

G

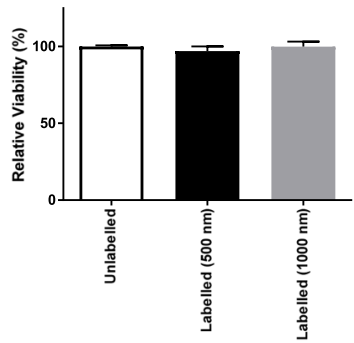

C
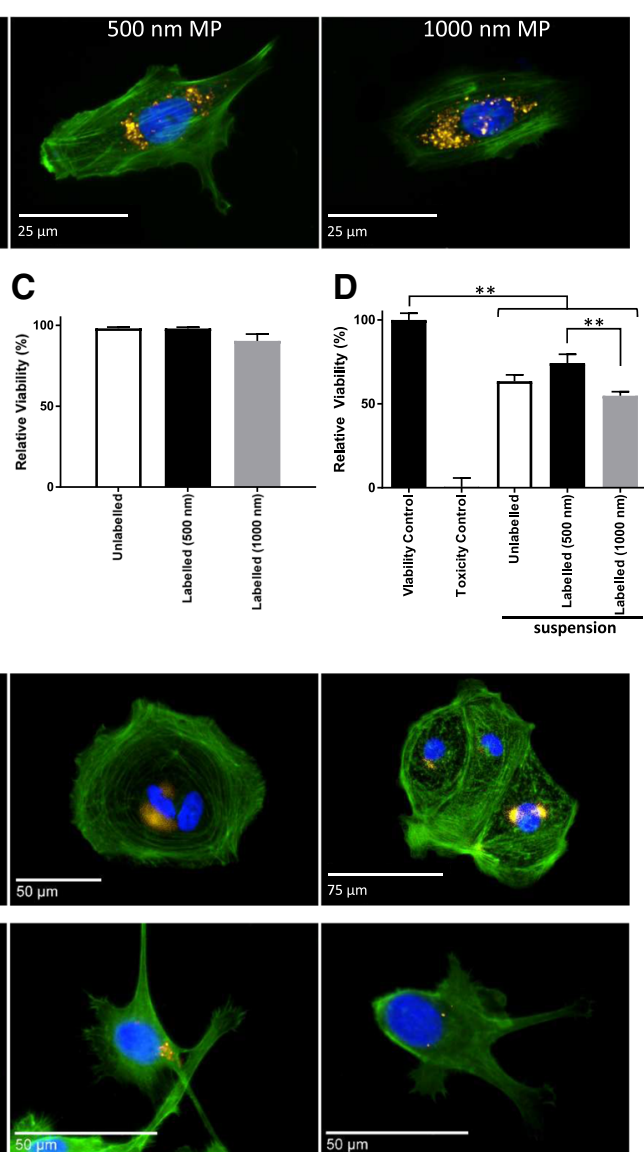

H

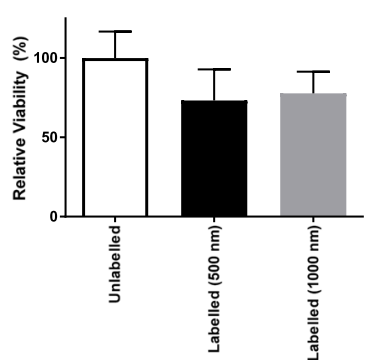

Fig. 3 Development of suspension cell labelling approach for human cells. a, b MP-labelled MSC examined by fluorescence microscopy $24 \mathrm{~h}$ post labelling (a), after staining with Phalloidin (green) and Hoechst 33342 (blue), and by flow cytometry (b). c, d MSC viability examined by membrane integrity assay (c) and metabolic activity measurement (d) $24 \mathrm{~h}$ post labelling. Viable control consisted of unlabelled monolayer cells, Toxicity control consisted of cells exposed to $70 \%$ methanol for 10 min. e, f Fluorescence microscopy evaluation of CMC (e) and ReN (f) following suspension labelling with $500 \mathrm{~nm}$ (middle panel) or $1000 \mathrm{~nm}$ (right panel) MPs (gold) compared to unlabelled cells (left panel), with Phalloidin (green) and Hoechst 33342 (blue) counterstain. g, h Metabolic activity for CMC (g) and ReN (h) 24 h post suspension labelling. Error bars presented as $\mathrm{SEM}, n=3 .{ }^{* *} P \leq 0.01$. MP magnetic particle

ReN cell types. Whilst the relationship between particle size and particle uptake is known [55], previous literature has reported that biological indicators such as cell density and proliferative state can affect uptake [56]; however, the role of cell size is less clear and may involve indirect links between biological processes and the MP physicochemical properties [57]. The reduced MP uptake in ReN may be related to their reduced ability to store particles in a reduced cytoplasmic volume [58], as internalised MPs have been shown to accumulate into perinuclear intracellular vesicles [38].

The maintenance of cell integrity upon labelling was confirmed by metabolic activity assays, found in agreement with a lack of senescence or cell cycle perturbation responses. These data are also in line with a lack of detectable DNA damage upon labelling [38]. Whilst iron 

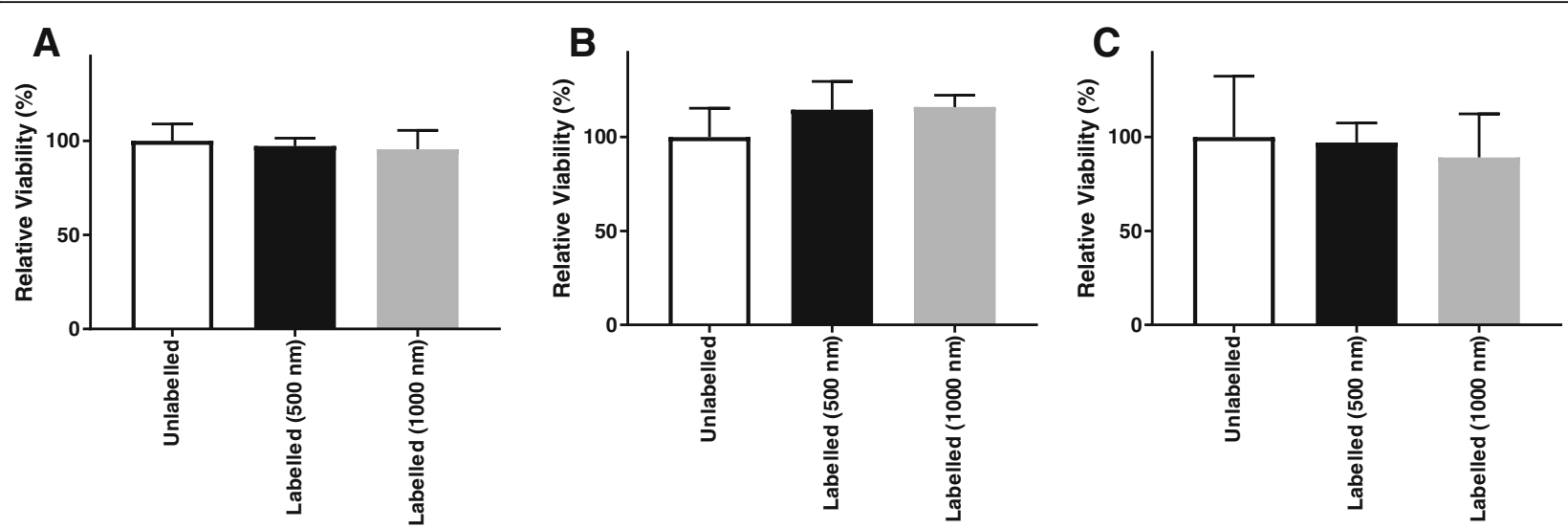

Fig. 4 Metabolic activity measurements of MP-labelled MSC (a), CMC (b) and ReN (c) after 24 h in HypoThermosol conditions. Error bars presented as SEM, $n=6$

particles have been suggested to cause oxidative damage leading to senescence in MSC populations [59], the results presented here are in line with previous reports suggesting there is no significant adverse effect on cells $[38,60,61]$. Both MSC and CMC demonstrated tolerance of MPs up to $100 \times$ standard dose $(1000 \mu \mathrm{g} / \mathrm{ml})$ which then led to a $50 \%$ reduction in relative viability. In $\mathrm{CMC}$, the $500 \mathrm{~nm}$ particles appeared to be more toxic than the $1000 \mathrm{~nm}$ particles. This could be linked to the increased surface area for smaller particles, previously hypothesised to lead to membrane wrapping effects [62, 63] and binding of a larger number of cell proteins [64]. ReN tolerated standard doses of MPs $(10 \mu \mathrm{g} / \mathrm{ml})$ with no reduction in viability; however, higher doses had a notable deleterious effect on cell attachment, preventing effective assessment. Overall, these findings are in line with the wider literature, reporting enhanced tolerance to MP labelling for MSC [38] and CMC [65]. Conversely, it has been suggested that neural stem cells are more susceptible to the iron contained in particles through an oxidative stress mechanism [65, 66]. Further assessments such as evaluation of senescence, apoptotic and autophagy responses could provide complementary parameters to assess and compare the finer cellular effects of high MP doses on different cell types.

$\mathrm{CMC}$ were further shown to maintain their functional capacity to beating following MP labelling, and cells were seen to change their morphology at doses exceeding $100 \mu \mathrm{g} / \mathrm{ml}$ but retained the ability to beat at even the highest dose $(1000 \mu \mathrm{g} / \mathrm{ml})$. Previous research on magnetic tissue engineering of cardiac sheets has investigated the effect that $10 \mathrm{~nm}$ magnetite particles may have on electrical connections between cells which may affect beating. This demonstrated no adverse effect [67], confirming our observations. Previous studies have suggested MSC function remains following MP labelling, with cells able to undergo multi-lineage differentiation into osteogenic, adipogenic and chondrogenic cell types [38]. This varies between studies, however, with some research groups demonstrating reduced markers of function including colony forming ability and differentiation potential [68]. This is likely due to the highly variable nature of MPs used throughout the field as well as a strong dose-responsive relationship between MPs and function [65]. Neural cells seem to have a reduced tolerance of labelling procedures, yet limited data suggest they do retain some function post labelling, with a study investigating MRI of transplanted labelled cells demonstrating substantial migration over time in vivo [69].

Efforts have been made to find clinically suitable labelling methods for iron oxide-based particles to ensure they effectively label the desired cell populations. For certain particles, which do not interact with cells, the use of a transfection agent to enhance labelling has proved successful [70]. Here we used an approach enabling the autonomous magnetic labelling of cells without the addition of other agents to the manufacturing process [38], and demonstrated its effectiveness in monolayers as well as suspension cultures for three human cell types. Suspension labelling demonstrated not only effectiveness but also retention of relative cell viability, with no statistically significant reduction when compared to unlabelled populations. This demonstration is of particular significance given the expected commercial significance of suspension culture methods such as stirred tank [50] or rocking $\mathrm{WAVE}^{\bullet}$ [71] bioreactors. These technologies represent an opportunity to significantly drive down the production cost of goods [72] and thus enhance market adoption of cell therapy [50], so the applicability of this labelling process represents an attractive route for integrating MPs with cell therapies.

When compared to monolayer MSC labelling, suspension cultures demonstrated a reduction in viability in all suspension populations, in the presence or absence of 


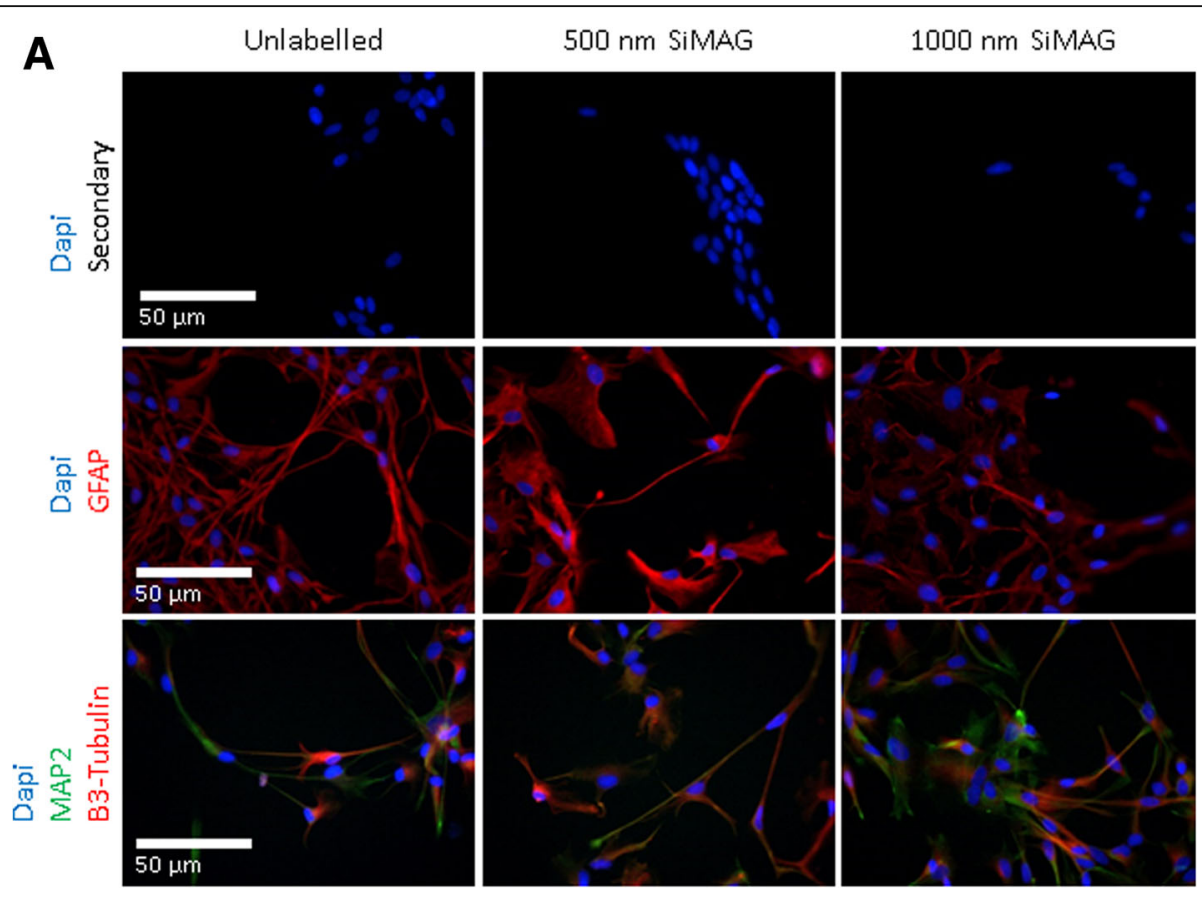

B
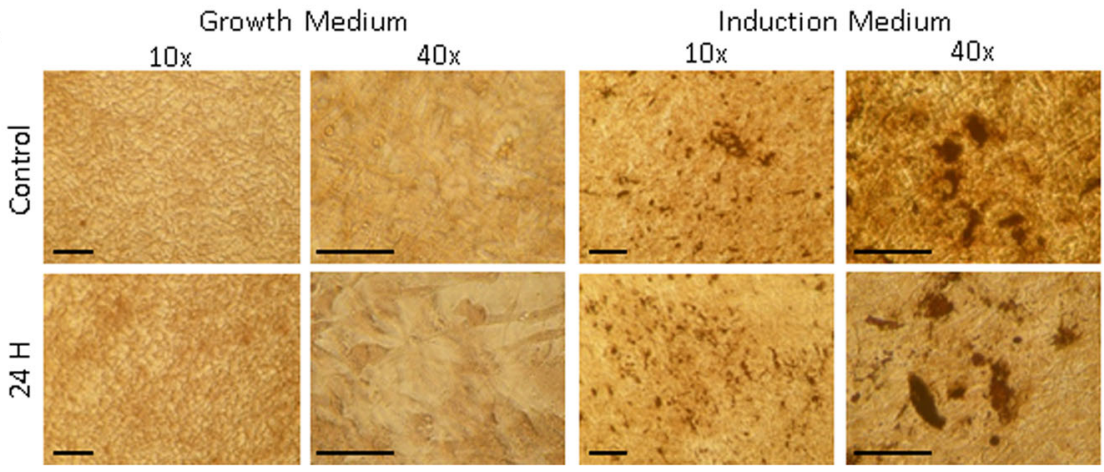

Fig. 5 Assessment of labelled MSC and ReN after HypoThermosol storage for $24 \mathrm{~h}$. a Differentiation of ReN analysed by immunodetection for MAP2, GFAP and $\beta 3$-tubulin expression following a 7-day differentiation protocol. Additional examination of CMC forming beating cardiomyocyte clusters and analysis of alpha actinin expression in MP-labelled cell populations exposed to HypoThermosol storage shown in Additional file 5: Figure S4. b Osteogenic differentiation of MP-labelled MSCs for 14 days, post incubation in HypoThermosol analysed using Von Kossa staining to highlight mineral deposits formed after 14 days under induction treatment. Scale bar $=125 \mu \mathrm{m}$

MPs, suggesting the cell pooling phase may require optimisation rather than the labelling process itself. Previous approaches have worked to bypass the requirement of adherent cell cultures for labelling success, instead opting for functionalised particle surfaces which drive targeted uptake through receptor mediated methods [73]. Both the $500 \mathrm{~nm}$ and the $1000 \mathrm{~nm}$ particles used here were shown to rapidly label adherent cultures and suspension culture. This suspension labelling methodology reduces the necessity for specific particle surface functionalisation in order to convey cell uptake traits. Rather, the particles are spontaneously taken up, which would allow functionalisation steps to be avoided.
In order to replicate the final step of a potential clinical therapy, the cell transport phase to the point of care, a low-temperature storage process was tested on MP-labelled cells using the HypoThermosol FRS product. This has previously been shown to maintain viability of a range of unlabelled cells such as pluripotent derived cardiac [74], mesenchymal [75] and neural [76] cell types. Here hypothermal exposure was tested on MP-labelled cells, and indicators of viability and function were examined.

MP-labelled neuroprogenitors were demonstrated to retain the ability to readily differentiate following simulated cold chain transport, as seen for unlabelled cells. This is in line with previous findings which demonstrated a retention of differentiation capacity following 
labelling [77]. Additionally, whilst both studies demonstrate retention of differentiation capacity, there are likely underlying long-term biological consequences. This is reflected in the observations during this research and previous literature [77] showing changes to cell morphology. This is potentially driven by the production of reactive oxygen species by the iron particles within the cells which are able to alter the internal regulatory mechanisms of neural stem cells [78].

Particle toxicity has previously been reported in neuronal and glial cell types [79]. In this study, MSC demonstrated retention of their ability to expand and form osteogenic cultures upon treatment. This is in line with previous published reports demonstrating retention of viability, colony forming ability and differentiation capacity of MSC populations following labelling with micron-sized iron oxide particles [80]. Additionally, the outcome of the osteogenic assay is in agreement with our previous observation that human MSC retain the ability to differentiate to all three lineages post labelling [38].

MP-labelled CMC were shown to remain functionally active following this hypothermal step, with cells resuming their beating activity when returned to normal culture conditions. When this was further examined with alpha actinin detection, it was noted that population purity had decreased, suggesting that storage may be affecting the mature CMC population to some degree. This contrasts with existing findings which reported CMC could tolerate similar hypothermal storage for up to 7 days [74], and suggests this slight decrease may be due to the presence of iron particles within the cells. Demonstrating the applicability of labelled cells for hypothermic storage is important in qualifying their use for this transport methodology. Hypothermic storage represents an attractive solution for cellular delivery as it removes any cryopreserved resuscitation step, thus simplifying the final formulation step at the clinical site [81].

\section{Conclusion}

Future prospects for precision medicine and regenerative medicine through the use of MPs are promising, and require careful process validation to ensure clinical need is addressed in the early stage of manufacturing design. This study suggests MP labelling could be incorporated into a cell manufacturing process for a range of therapeutically relevant cell types. Furthermore, MP-labelled cell populations were shown to withstand low-temperature storage without significantly impacting indicators of cell function, suggesting the process would be compatible with cold chain transport. These results suggest that MP-based theranostics can be effectively integrated into cell manufacturing processes to support their use in future potential cell therapies.

\section{Additional files}

\begin{abstract}
Additional file 1: Figure S1. Maintenance of cell integrity after cell labelling with $1000 \mathrm{~nm}$ SiMAG for MSC. (A) Live/dead cell assay (live, green; dead, red) showing live cell fractions remaining above the toxicity threshold (dashed line). Scale bar: $100 \mu \mathrm{m}$. (B) Senescence assay (blue signal) showing no significant change upon labelling. Scale bar: $50 \mu \mathrm{m}$. (C) Cell cycle analysis showing no significant difference between unlabelled and labelled cell populations. ${ }^{* *} p<0.01,{ }^{* * *} p<0.001$ (TIF $445 \mathrm{~kb}$ )
\end{abstract}

Additional file 2: Supplementary materials and methods (DOCX $14 \mathrm{~kb}$ )

Additional file 3: Figure S2. Beating cardiomyocyte cell cluster showing particles distributed across its mass. Demonstration of viable beating cells with fluorescent particles allowing imaging and tracking of particles in real time. Cells stained with Calcein AM (green) and labelled with SiMAG (red) (WMV $6783 \mathrm{~kb}$ )

Additional file 4: Figure S3. Video of beating CMC colonies. Morphology and ability of cardiomyocytes to beat following labelling demonstrated that cells retain the ability to beat even at the highest doses (WMV $4259 \mathrm{~kb}$ )

Additional file 5: Figure S4. Cardiomyocytes labelled with SiMAG resuming beating following refrigerated storage. Following incubation of cardiomyocytes with HypoThermosol in refrigerated conditions, cells were assessed to determine whether they resumed beating. They were found to beat within $12 \mathrm{~h}$ of being removed from refrigerated storage even when labelled with SiMAG (WMV $7173 \mathrm{~kb}$ )

Additional file 6: Figure S5. Assessment of labelled CMC after HypoThermosol storage for $24 \mathrm{~h}$. Image analysis performed examining alpha actinin expression in MP-labelled cell populations exposed to HypoThermosol storage. Error bars presented as SEM, $n=3$ (TIF $25 \mathrm{~kb}$ )

\section{Abbreviations}

CMC: Cardiomyocytes; iPS: Induced pluripotent stem cell; MP: Magnetic particle; MSC: Mesenchymal stem cells; ReN: Neural progenitor cells

\section{Acknowledgements}

The authors are grateful to Dr Robert Markus for his expert help with superresolution microscopy, and to N. de Melo and Z. Nizamudeen for helpful discussions on image analysis. The authors wish to thank Prof. Ellen Billett (Nottingham Trent University) for the kind gift of the SHSY5Y cell line.

\section{Funding}

This work was supported by the Engineering and Physical Sciences Research Council (grant numbers 1118937 and EP/I017801/1) and the University of Nottingham Discipline Bridging Award. Super-resolution microscopy was conducted in the School of Life Sciences Imaging facility (SLIM) supported by the Biotechnology and Biological Sciences Research Council (grant number BB/L013827/1)

\section{Availability of data and materials}

The datasets used and/or analysed during the current study are available from the corresponding author on reasonable request.

\section{Authors' contributions}

$\mathrm{RH}$ and VS planned and designed the project. $\mathrm{RH}$ carried out the laboratory work with the support of HALL, SS, SM and JC. RH analysed the data and assembled figures and supporting information with a contribution from HALL. RH and VS finalised the manuscript. All authors contributed to scientific discussion of the study. All authors read and approved the final manuscript.

\section{Ethics approval and consent to participate}

Not applicable.

\section{Consent for publication}

Not applicable.

Competing interests

The authors declare that they have no competing interests. 


\section{Publisher's Note}

Springer Nature remains neutral with regard to jurisdictional claims in published maps and institutional affiliations.

\section{Author details}

'Wolfson Centre for Stem Cells, Tissue Engineering and Modelling (STEM), School of Medicine, The University of Nottingham, Nottingham NG7 2RD, UK. ${ }^{2}$ Institute for Science and Technology in Medicine-Keele University, Stoke-on-Trent ST4 7QB, UK.

Received: 23 April 2018 Revised: 26 July 2018 Accepted: 2 August 2018 Published online: 26 September 2018

\section{References}

1. Rivière I, Roy K. Perspectives on manufacturing of high-quality cell therapies. Mol Ther. 2017;25:1067-8. https://doi.org/10.1016/j.ymthe.2017.04.010.

2. Harrison RP, Ruck S, Medcalf N, Rafiq QA. Decentralized manufacturing of cell and gene therapies, overcoming challenges and identifying opportunities. Cytotherapy. 2017;19:1140-51.

3. Zylberberg C, Charo A, Haddock R, Lin-Gibson S, Lumelsky N, Petersen T, et al. Manufacturing cell therapies: the paradigm shift in healthcare of this century. NAM Perspect. 2017; in press. https://doi.org/10.31478/201706c.

4. Harrison RP, Medcalf N, Rafiq QA. Cell therapy processing economics: small scale micro-factories as a stepping stone towards large scale macro-factories. Regen Med. 2018;13(2):159-73. https://doi.org/10.2217/ rme-2017-0103.

5. Rowley J, Abraham E, Campbell A, Brandwein H, Oh S. Meeting lot-size challenges of manufacturing adherent cells for therapy. Bioprocess Int. 2012; 10:16-22

6. El Haj AJ, Glossop JR, Sura HS, Lees MR, Hu B, Wolbank S, et al. An in vitro model of mesenchymal stem cell targeting using magnetic particle labelling. J Tissue Eng Regen Med. 2015;9:724-33. https://doi.org/10.1002/ term.1636.

7. Tang KS, Hann B, Shapiro EM. On the use of micron-sized iron oxide particles (MPIOS) to label resting monocytes in bone marrow. Mol Imaging Biol. 2011;13:819-24. https://doi.org/10.1007/s11307-010-0437-3.

8. Kolosnjaj-Tabi J, Wilhelm C, Clément O, Gazeau F. Cell labeling with magnetic nanoparticles: opportunity for magnetic cell imaging and cell manipulation. J Nanobiotechnology. 2013;11(Suppl 1):S7. https://doi.org/10. 1186/1477-3155-11-S1-S7.

9. Elias A, Tsourkas A. Imaging circulating cells and lymphoid tissues with iron oxide nanoparticles. Nanotechnol Haematol. 2009:1:720-6.

10. Gilchrist R, Medal R. Selective inductive heating of lymph nodes. Ann Surg. 1957:146:596-606

11. Pankhurst CJ, Jones SK, Dobson J. Applications of magnetic nanoparticles in biomedicine J Phys D. 2003:36:167.

12. Pankhurst $\mathrm{Q}$, Thanh $\mathrm{N}$, Jones $\mathrm{S}$, Dobson J. Progress in applications of magnetic nanoparticles in biomedicine. 2009:224001:1-15. https:/doi.org/ 10.1088/0022-3727/42/22/224001

13. Cohen Y, Shoushan SY. Magnetic nanoparticles-based diagnostics and theranostics. Curr Opin Biotechnol. 2013;24(4):672-81. https://doi.org/10. 1016/j.copbio.2013.01.006.

14. Mosaiab T, Jeong CJ, Shin GJ, Choi KH, Lee SK, Lee I, et al. Recyclable and stable silver deposited magnetic nanoparticles with poly (vinyl pyrrolidone)catechol coated iron oxide for antimicrobial activity. Mater Sci Eng C. 2013; 33:3786-94. https://doi.org/10.1016/j.msec.2013.05.009.

15. Riedinger A, Guardia P, Curcio A, Garcia M a, Cingolani R, Manna L, et al, Subnanometer local temperature probing and remotely controlled drug release based on azo-functionalized iron oxide nanoparticles. Nano Lett. 2013;13:2399-406. https://doi.org/10.1021/n/400188q

16. Glover AL, Bennett JB, Pritchett JS, Nikles SM, Nikles DE, Nikles J a, et al. Magnetic heating of Iron oxide nanoparticles and magnetic micelles for cancer therapy. IEEE Trans Magn. 2013;49:231-5. https://doi.org/10.1109/ TMAG.2012.2222359.

17. Shapiro E, Skrtic S, Sharer K, Hill J, Dunbar C, Koretsky A. MRI detection of single particles for cellular imaging. Proc Natl Acad Sci U S A. 2004;101: 10901-6. https://doi.org/10.1073/pnas.0403918101.

18. Sasaki H, Tanaka N, Nakanishi K, Nishida K, Hamasaki T, Yamada K, Ochi M. Therapeutic effects with magnetic targeting of bone marrow stromal cells in a rat spinal cord injury model. Spine. 2011;36(12):933-8. https://doi.org/ 10.1097/BRS.0b013e3181eb9fb0.
19. Borthakur a, Shapiro EM, Beers J, Kudchodkar S, Kneeland JB, Reddy R. Sensitivity of MRI to proteoglycan depletion in cartilage: comparison of sodium and proton MRI. Osteoarthr Cartil. 2000;8:288-93. https://doi.org/10. 1053/joca.1999.0303.

20. Hughes S, El Haj AJ, Dobson J. Magnetic micro- and nanoparticle mediated activation of mechanosensitive ion channels. Med Eng Phys. 2005:27:75462. https://doi.org/10.1016/j.medengphy.2005.04.006.

21. Strijkers G, Mulder M, Willem J, Van Tilborg F, Geralda A, Nicolay K. MRI contrast agents: current status and future perspectives. Anti Cancer Agents Med Chem. 2007;7:291-305. https://doi.org/10.2174/187152007780618135.

22. Akella SV, Regatte RR, Gougoutas aJ, Borthakur a, Shapiro EM, Kneeland $\mathrm{JB}$, et al. Proteoglycan-induced changes in T1rho-relaxation of articular cartilage at 4T. Magn Reson Med. 2001;46:419-23. https://doi.org/10. 1002/mrm.1208

23. Dick AJ. Magnetic resonance fluoroscopy allows targeted delivery of mesenchymal stem cells to infarct borders in swine. Circulation. 2003;108: 2899-904. https://doi.org/10.1161/01.CIR.0000095790.28368.F9.

24. Chen H, Kaminski MD, Pytel P, Macdonald L, Rosengart AJ. Capture of magnetic carriers within large arteries using external magnetic fields. J Drug Target. 2008;16:262-8. https://doi.org/10.1080/10611860801900892.

25. Kyrtatos PG, Lehtolainen P, Junemann-Ramirez M, Garcia-Prieto A, Price AN, Martin JF, et al. Magnetic tagging increases delivery of circulating progenitors in vascular injury. JACC Cardiovasc Interv. 2009;2:794-802. https://doi.org/10.1016/j.jcin.2009.05.014

26. Pislaru SV, Harbuzariu A, Gulati R, Witt T, Sandhu NP, Simari RD, et al. Magnetically targeted endothelial cell localization in stented vessels. J Am Coll Cardiol. 2006;48:1839-45. https://doi.org/10.1016/j.jacc.2006.06.069.

27. Polyak B, Fishbein I, Chorny M, Alferiev I, Williams D, Yellen B, et al. High field gradient targeting of magnetic nanoparticle-loaded endothelial cells to the surfaces of steel stents. Proc Natl Acad Sci U S A. 2008:105:698-703. https://doi.org/10.1073/pnas.0708338105.

28. Riegler J, Wells JA, Kyrtatos PG, Price AN, Pankhurst QA, Lythgoe MF. Targeted magnetic delivery and tracking of cells using a magnetic resonance imaging system. Biomaterials. 2010;31:5366-71. https://doi.org/10. 1016/j.biomaterials.2010.03.032.

29. Landázuri N, Tong S, Suo J, Joseph G, Weiss D, Sutcliffe DJ, et al. Magnetic targeting of human mesenchymal stem cells with internalized superparamagnetic Iron oxide nanoparticles. Small. 2013;9:4017-26. https:// doi.org/10.1002/smll.201300570.

30. Cheng L, Wang C, Ma X, Wang Q, Cheng Y, Wang H, et al. Multifunctional upconversion nanoparticles for dual-modal imaging-guided stem cell therapy under remote magnetic control. Adv Funct Mater. 2013;23:272-80. https://doi.org/10.1002/adfm.201201733.

31. Yanai A, Häfeli UO, Metcalfe AL, Soema P, Addo L, Gregory-Evans CY, et al, Focused magnetic stem cell targeting to the retina using superparamagnetic iron oxide nanoparticles. Cell Transplant. 2012;21:1137-48. https://doi.org/10. $3727 / 096368911 \times 627435$

32. Ito A, Hibino E, Kobayashi $C$, Terasaki $H$, Kagami $H$, Ueda $M$, et al. Construction and delivery of tissue-engineered human retinal pigment epithelial cell sheets, using magnetite nanoparticles and magnetic force. Tissue Eng. 2005:11:489-96. https://doi.org/10.1089/ten.2005.11.489.

33. Nishida K, Tanaka N, Nakanishi K, Kamei N, Hamasaki T, Yanada S, et al. Magnetic targeting of bone marrow stromal cells into spinal cord: through cerebrospinal fluid. Neuroreport. 2006;17:1269-72. https://doi.org/10.1097/ 01.wnr.0000227993.07799.a2.

34. Arbab AS, Jordan EK, Wilson LB, Yocum GT, Lewis BK, Frank JA. In vivo trafficking and targeted delivery of magnetically labeled stem cells. Hum Gene Ther. 2004;15:351-60. https://doi.org/10.1089/104303404322959506.

35. Forte A, Finicelli M, Mattia M, Berrino L, Rossi F, De Feo M, et al. Mesenchymal stem cells effectively reduce surgically induced stenosis in rat carotids. J Cell Physiol. 2008;217:789-99. https://doi.org/10.1002/jcp.21559.

36. Wang $\mathrm{CH}$, Cherng WJ, Yang NI, Kuo LT, Hsu CM, Yeh HI, et al. Lateoutgrowth endothelial cells attenuate intimal hyperplasia contributed by mesenchymal stem cells after vascular injury. Arterioscler Thromb Vasc Biol. 2008;28:54-60. https://doi.org/10.1161/ATVBAHA.107.147256.

37. Ventola CL. The nanomedicine revolution: part 2: current and future clinical applications. Pharm Ther. 2012;37:582-91.

38. Harrison R, Markides H, Morris RH, Richards P, El Haj AJ, Sottile V, et al. Autonomous magnetic labelling of functional mesenchymal stem cells for improved traceability and spatial control in cell therapy applications. J Tissue Eng Regen Med. 2016;11:2333-48. https://doi.org/10.1002/term. 
39. Sottile $\mathrm{V}$, Thomson A, McWhir J. In vitro osteogenic differentiation of human ES cells. Cloning Stem Cells. 2003;5:149-55. https://doi.org/10.1089/ 153623003322234759.

40. Ahmad A, Strohbuecker S, Tufarelli C, Sottile V. Expression of a SOX1 overlapping transcript in neural differentiation and cancer models. Accept Publ Cell Mol Life Sci. 2017;74:4245-58. https://doi.org/10.1007/s00018-0172580-3.

41. Burridge PW, Matsa E, Shukla P, Lin ZC, Churko JM, Ebert AD, et al. Chemically defined generation of human cardiomyocytes. Nat Methods. 2014;11:855-60. https://doi.org/10.1038/nmeth.2999.

42. Beausoleil SA, Jedrychowski M, Schwartz D, Elias JE, Villén J, Li J, et al. Large-scale characterization of HeLa cell nuclear phosphoproteins. Proc Natl Acad Sci U S A. 2004;101:12130-5. https://doi.org/10.1073/pnas. 0404720101.

43. Wang L, Park P, Lin C-Y. Characterization of stem cell attributes in human osteosarcoma cell lines. Cancer Biol Ther. 2009;8:543-52. https://doi.org/10. 4161/cbt.8.6.7695.

44. Biedler JL, Helson L, Spengler BA. Morphology and growth, tumorigenicity, and cytogenetics of human neuroblastoma cells in continuous culture. Cancer Res. 1973;33:2643-52.

45. Hidalgo IJ, Raub TJ, Borchardt RT. Characterization of the human colon carcinoma cell line (Caco-2) as a model system for intestinal epithelial permeability. Gastroenterology. 1989;96:736-49.

46. Markides $\mathrm{H}$, Kehoe $\mathrm{O}$, Morris RH, El Haj AJ. Whole body tracking of superparamagnetic iron oxide nanoparticle-labelled cells - a rheumatoid arthritis mouse model. Stem Cell Res Ther. 2013;4:1-14. https://doi.org/10. $1186 /$ scrt337.

47. ThermoFisher Scientific. Actin staining protocol 2017. https://www. thermofisher.com/uk/en/home/references/protocols/cell-and-tissue-analysis/ protocols/actin-green-488-readyprobes-protocol.html. Accessed 25 Aug 2017.

48. Wang Y-H, Liu Y, Maye P, Rowe DW. Examination of mineralized nodule formation in living osteoblastic cultures using fluorescent dyes. Biotechnol Prog. 2006;22:1697-701. https://doi.org/10.1021/bp060274b.

49. Pal R, Hanwate M, Totey SM. Effect of holding time, temperature and different parenteral solutions on viability and functionality of adult bone marrow-derived mesenchymal stem cells before transplantation. J Tissue Eng Regen Med. 2008;2:436-44. https://doi.org/10.1002/term.109.

50. Heathman TRJ, Nienow W, Mccall MJ, Coopman K, Kara B, Hewitt CJ. The translation of cell-based therapies: clinical landscape and manufacturing challenges. Regen Med. 2015;10(1):49-64. https://doi.org/10.2217/rme.14.73.

51. Yen SK, Padmanabhan P, Selvan ST. Multifunctional iron oxide nanoparticles for diagnostics, therapy and macromolecule delivery. Theranostics. 2013; 3(12):986-1003. https://doi.org/10.7150/thno.4827.

52. Li L, Jiang W, Luo K, Song H, Lan F, Wu Y, et al. Superparamagnetic iron oxide nanoparticles as MRI contrast agents for non-invasive stem cell labeling and tracking. Theranostics. 2013;3:595-615. https://doi.org/10.7150/ thno.5366.

53. Harrison RP, Rafiq QA, Medcalf N. Automating decentralized manufacturing of cell \& gene therapy products. Cell Gene Ther Insights. 2016;2:115-20. https://doi.org/10.18609/cgti.2016.014.

54. Hourd P, Chandra A, Medcalf N, Williams DJ. Regulatory challenges for the manufacture and scale-out of autologous cell therapies. StemBook, ed. The Stem Cell Research Community, StemBook. 2014; https://doi.org/10.3824/ stembook.1.96.1

55. Desai MP, Labhasetwar V, Walter E, Levy RJ, Amidon GL. The mechanism of uptake of biodegradable microparticles in Caco-2 cells is size dependent. Pharm Res. 1997;14:1568-73. https://doi.org/10.1023/A:1012126301290.

56. Zauner W, Farrow NA, Haines AM. In vitro uptake of polystyrene microspheres: effect of particle size, cell line and cell density. J Contro Release. 2001;71:39-51. https://doi.org/10.1016/S0168-3659(00)00358-8.

57. Colombo M, Carregal-Romero S, Casula MF, Gutiérrez L, Morales MP, Böhm IB, et al. Biological applications of magnetic nanoparticles. Chem Soc Rev. 2012;41:4306-34. https://doi.org/10.1039/c2cs15337h.

58. Mornet S, Vasseur S, Grasset F, Duguet E. Magnetic nanoparticle design for medical diagnosis and therapy. J Mater Chem. 2004;14:2161-75. https://doi. org/10.1039/b402025a

59. Yang F, Yang L, Li Y, Yan G, Feng C, Liu T, et al. Melatonin protects bone marrow mesenchymal stem cells against iron overload-induced aberrant differentiation and senescence. J Pineal Res. 2017;63:1-18. https://doi.org/10. 1111/.jpi.12422.
60. Wimpenny I, Markides H, El Haj AJ. Orthopaedic applications of nanoparticle-based stem cell therapies. Stem Cell Res Ther. 2012;3:1-12. https://doi.org/10.1186/scrt104.

61. Markides H, Rotherham M, El Haj AJ. Biocompatibility and toxicity of magnetic nanoparticles in regenerative medicine. J Nanomater. 2012;2012: 1-11. https://doi.org/10.1155/2012/614094.

62. Zhao SX, Zhang G, Trewyn BG, Slowing II, Lin VS-Y. Interaction of mesoporous silica nanoparticles with human red blood cell membranes: size and surface effects. ACS Nano. 2011;5:1366-75. https://doi.org/10.1021/nn103077k.

63. Slowing II, Wu C-W, Vivero-Escoto JL, Lin VS-Y. Mesoporous silica nanoparticles for reducing hemolytic activity towards mammalian red blood cells. Small. 2009;5:57-62. https://doi.org/10.1002/smll.200800926.

64. Wiogo HTR, Lim M, Bulmus V, Yun J, Amal R. Stabilization of magnetic iron oxide nanoparticles in biological media by fetal bovine serum (FBS). Langmuir. 2011;27:843-50. https://doi.org/10.1021/la104278m.

65. Laurent S, Burtea C, Thirifays C, Häfeli UO, Mahmoudi M. Crucial ignored parameters on nanotoxicology: the importance of toxicity assay modifications and "cell vision". PLoS One. 2012;7:e29997. https://doi.org/10. 1371/journal.pone.0029997.

66. Mahmoudi M, Azadmanesh K, Shokrgozar MA, Journeay WS, Laurent S. Effect of nanoparticles on the cell life cycle. Chem Rev. 2011;111(5):3407-32. https://doi.org/10.1021/cr1003166.

67. Shimizu K, Ito A, Lee J-K, Yoshida T, Miwa K, Ishiguro H, et al. Construction of multi-layered cardiomyocyte sheets using magnetite nanoparticles and magnetic force. Biotechnol Bioeng. 2007;96:803-9. https://doi.org/10.1002/ bit.21094.

68. Schäfer R, Bantleon R, Kehlbach R, Siegel G, Wiskirchen J, Wolburg H, et al. Functional investigations on human mesenchymal stem cells exposed to magnetic fields and labeled with clinically approved iron nanoparticles. BMC Cell Biol. 2010;11:22. https://doi.org/10.1186/1471-2121-11-22.

69. Berman SC, Galpoththawela C, Gilad AA, Bulte JWM, Walczak P. Long-term MR cell tracking of neural stem cells grafted in immunocompetent versus immunodeficient mice reveals distinct differences in contrast between live and dead cells. Magn Reson Med. 2011;65:564-74. https://doi.org/10.1002/ mrm.22613

70. Frank JA, Miller BR, Arbab AS, Zywicke HA, Jordan EK, Lewis BK, et al. Clinically applicable labeling of mammalian and stem cells by combining superparamagnetic iron oxides and transfection agents. Radiology. 2003; 228:480-7. https://doi.org/10.1148/radiol.2281020638.

71. Timmins NE, Palfreyman E, Marturana F, Dietmair S, Luikenga S, Lopez G, et al. Clinical scale ex vivo manufacture of neutrophils from hematopoietic progenitor cells. Biotechnol Bioeng. 2009;104:832-40. https://doi.org/10.1002/bit.22433.

72. Simaria AS, Hassan S, Varadaraju H, Rowley J, Warren K, Vanek P, et al. Allogeneic cell therapy bioprocess economics and optimization: single-use cell expansion technologies. Biotechnol Bioeng. 2014;111:69-83. https://doi. org/10.1002/bit.25008.

73. Di Maggio N, Martella E, Meikle S, Columbaro M, Lucarelli E, Santin M, et al. Rapid and efficient magnetization of mesenchymal stem cells by dendrimer-functionalized magnetic nanoparticles. Nanomedicine. 2016;11: 1519-34. https://doi.org/10.2217/nnm-2016-0085.

74. Correia C, Koshkin A, Carido M, Espinha N, Šarić T, Lima PA, et al. Effective hypothermic storage of human pluripotent stem cell-derived cardiomyocytes compatible with global distribution of cells for clinical applications and toxicology testing. Stem Cells Transl Med. 2016;5:658-69. https://doi.org/10.5966/sctm.2015-0238.

75. Ginis I, Grinblat B, Shirvan MH. Evaluation of bone marrow-derived mesenchymal stem cells after cryopreservation and hypothermic storage in clinically safe medium. Tissue Eng Part C Methods. 2012;18:453-63. https:// doi.org/10.1089/ten.tec.2011.0395.

76. El Akabawy G, Rattray I, Gale R, Bates G, Modo M, Neuroscience B. Implantation of undifferentiated and predifferentiated human neural stem cells in the R6/2 transgenic mouse model of Huntington's disease. BMC Neurosci. 2012;13 https://doi.org/10.1186/1471-2202-13-97.

77. Umashankar A, Corenblum MJ, Ray S, Valdez M, Yoshimaru ES, Trouard TP, et al. Effects of the iron oxide nanoparticle Molday ION Rhodamine B on the viability and regenerative function of neural stem cells: relevance to clinical translation. Int J Nanomedicine. 2016;11:1731-48. https://doi.org/10. 2147/IJN.S102006.

78. Madhavan L. Redox-based regulation of neural stem cell function and Nrf2. Biochem Soc Trans. 2015;43:627-31. https://doi.org/10.1042/ BST20150016. 
79. Sakhtianchi R, Minchin RF, Lee K-B, Alkilany AM, Serpooshan V, Mahmoudi M. Exocytosis of nanoparticles from cells: role in cellular retention and toxicity. Adv Colloid Interf Sci. 2013;201-202:18-29. https://doi.org/10.1016/j. cis.2013.10.013.

80. Hinds KA, Hill JM, Shapiro EM, Laukkanen MO, Silva AC, Combs CA, et al. Highly efficient endosomal labeling of progenitor and stem cells with large magnetic particles allows magnetic resonance imaging of single cells. Blood. 2003;102:867-72. https://doi.org/10.1182/blood-2002-12-3669.

81. Coopman K, Medcalf N. From production to patient: challenges and approaches for delivering cell therapies. StemBook, ed. The StemCell Research Community, StemBook. https://doi.org/10.3824/stembook.1.97.1.

Ready to submit your research? Choose BMC and benefit from:

- fast, convenient online submission

- thorough peer review by experienced researchers in your field

- rapid publication on acceptance

- support for research data, including large and complex data types

- gold Open Access which fosters wider collaboration and increased citations

- maximum visibility for your research: over $100 \mathrm{M}$ website views per year

At $\mathrm{BMC}$, research is always in progress.

Learn more biomedcentral.com/submissions 